Ostashko,1997 - Ostashko T. Tovarystvo «Prosvita» - oseredky ukrainskoho natsionalno-osvitnoho rukhu za doby Tsentralnoi Rady [Society «Enlightenment» is a center of the Ukrainian national educational movement during the Central Rada] // Tsentralna Rada i ukrainskyi derzhavotvorchyi protses (do 80-richchia stvorennia Tsentralnoi Rady): Materialy nauk. konf., 20 bereznia 1997 r. NAN Ukrainy, In-t istorii Ukrainy. K., 1997. Ch. 2. S. 272-280. [in Ukrainian].

Reient, 2003 - Reient O. Ukraina v impersku dobu (XIX - pochatok XX st.) [Ukraine in the imperial era (XIX - early XX centuries)]. K., 2003. 338 s. [in Ukrainian].

Sarbei, 1999 - Sarbei V. Natsionalne vidrodzhennia Ukrainy [National revival of Ukraine]. K., 1999. 335 s. [in Ukrainian].

U mistechku Pokotylove, 1917 - U mistechku Pokotylove...1917 [In the town of Pokotylove... 1917] - Chytalnia. Nova Rada. (Kyiv). 26 chervnia. [in Ukrainian].

U s. Tykhomu Khutori, 1917 - U s. Tykhomu Khutori...1917 [In the village of Tykhy Khutir] - «Prosvita». Nova Rada. (Kyiv). 1 zhovtnia. [in Ukrainian].

Faryna, 1993 - Faryna S. Ya. Rol «Prosvit»v ukrainskomu natsionalno-kulturnomu rusi na pochatku KhKh stolittia [The role of «Enlightenment» in the Ukrainian national and cultural movement in the early XIX century].: dys. ... kand. ist. nauk: 07.00.01. Kremenchuk, 1993. 233 s. [in Ukrainian].

TsDAVO Ukrainy - Tsentralnyi derzhavnyi arkhiv vyshchykh orhaniv vlady ta upravlinnia Ukrainy.

УДК 94(477.46)"1921/1923":939.52

Ігор ОПАЦЬКИЙ,

orcid.org/0000-0002-6786-3295

кандидат історичних наук, викладач кафедри історіі України

Уманського державного педагогічного університету імені Павла Тичини

(Україна, Умань)

igor.opatskiy@gmail.com

\title{
ГОЛОД 1921-1923 РР. НА УМАНЩИНІ (ЗА МАТЕРІАЛАМИ АРХІВУ РОДИНИ КУРІННИХ)
}

У статті проаналізовано еgо-документи родини Курінних (передусім щуоденник Петра Федоровича Курінного та особисте листування йог осина Петра Петровича Курінного). Наголошено на основних причинах голоду 1921-1923 рр., його масштаби на території історичної Уманщчини. Результатом наукової розвідки є систематизація відомостей з архіву родини Курінних про голод, основні заходи більшовицької влади зі збору податків, вилучення продовольства у населення, здійснення репресивних заходів у боротьбі з селянським повстанським рухом.

Ключові слова: Уманщчина, голод 1921-1923 рр., Петро Курінний, білошовицький режим, воєнний комунізм.

Ihor OPATSKYI,

Candidate of Historical Sciences, lecturer of history of Ukraine Department Pavlo Tychyna Uman State Pedagogical University

(Uman, Ukraine)

igor.opatskiy@gmail.com

\section{THE FAMINE OF 1921-1923 IN THE UMAN REGION (BASED ON THE MATERIAL FROM THE KURINNYIS FAMILY ARCHIVE)}

The article analyses the ego-documents of the Kurinnyis family (in the first place, Petro F. Kurinnyi's diary and the personal correspondence of his son Petro P. Kurinnyi). The main reasons for the famine of 1921-1923 and its scale on the territory of the historical Uman region are noted. The result of scientific research is the systematization of 
information from the Kurinnyis family archive about the famine, the main measures of the Bolshevik government to collect taxes, the food confiscation from the population and the implementation of repressive measures in order to fight against the peasant insurrectionary movement. The main thesis of the article is a study of the reflection of the theme of the famine of 1921-1923 in the Uman region in the ego-documents of the Kurinnyis family.

The diary entries of Petro F. Kurinnyi (1852 - 1931) for 1921-1922 are analysed, which reflect the main events that led to the famine. In addition to unfavourable weather conditions, the author highlights such measures of the Soviet government that destabilized the situation with the provision of food for the population: exorbitant taxes, contributions, repression of wealthy peasants. These records confirm the opinion that the causes of the famine of 1921-1923 were unfavourable weather conditions and actions of the Soviet government.

The article draws attention to the soaring inflation prior to the monetary reform was introduced. It was recorded that prices in the Uman region grew several times weekly, and the population refused to accept Soviet money. Trading was conducted under a barter system. The most important commodity was grain, which often served as money. In the Uman region, many refugees from starving southern provinces sold various goods in order to buy some food. A large number of exhausted and starving people died in railway cars and at stations where they froze to death without getting any wheat.

Bolsheviks' human resource management is analysed. In particular, it is noted that the Committee of Poor Peasants consisted mainly of people without education and with a dubious background. They implemented the Bolshevik policy in the countryside and conducted the requisition of food. The article reflects how the diet of the Kurinnyis family changed. In particular, it was noted that a previously wealthy family was on the verge of starvation and often did not have the opportunity to purchase food. It is noted that the famine of 1921-1923 had the greatest distribution in the south of Ukraine. However, the Uman region, located near the border with the southern provinces, also suffered from the problem of hunger. Unfavourable weather conditions, unbearable taxes, the requisition of food, the imposition of contributions upon settlements, inflation and other measures of the Soviet government led to the spread of the famine in the Uman region.

Thus, the article traces the reasons for the famine of 1921-1923 based on the analysis of the ego-documents of the Kurinnyis family in the Uman region. Its scale has been determined. The process of exclusion of church values is shown. The spring sowing campaign of 1922 yielded disappointing results. Intensive confiscation of wheat led to the underfulfilment of a sowing-plan. The animal husbandry crisis also reached its climax. The livestock population dropped significantly. That allows us to conclude that the famine of 1921-1923 in the Uman region was caused by the excessive confiscation of wheat and its transfer outside the republic.

Key words: Uman region, famine of 1921-1923, Petro Kurinny, Beloshovytsia regime, military communism.

Постановка проблеми. Голод 1921-1923 pp. офіційно визнавався радянською владою, однак інформацію про нього було спотворено ідеологічною системою. Факт голоду не замовчувався від міжнародної спільноти, однак у 1921 р. голод на Півдні України затінявся інформацією про голод на Поволжі, куди спрямовувалася міжнародна гуманітарна допомога та зерно з голодуючої України. Лише 31922 р. українці почали отримувати продовольчі пайки від гуманітарних місій. Голод 1920-х рр. висвітлювалася радянською історіографією у спрощеному вигляді. Окрім природних чинників та воєнної розрухи мав і соціальні причини, зумовлені економічною політикою більшовицької влади, однак в СРСР ці причини замовчувалися. 3 відновленням незалежності України про політичні та воєнні причини голоду почали з'являтися дослідження вчених, однак у суспільній свідомості катастрофа 19211923 рр. затінялася трагедією Голодомору-геноциду 1932-1933 рр. Традиційно, цьогоріч в Україні відбулися офіційні заходи з вшанування пам'яті жертв Голодоморів, зокрема 100-річчя від початку масового голоду на Півдні України у 1921 р. Вшанування 100-річчя від початку голоду актуалізус звернення до цієї теми та висвітлення раніше невідомих $\dddot{1 і}$ аспектів. Одним з таких аспектів $\epsilon$ подіï 1921-1923 рр. на території історичної Уманщини. Ця територія була неподалік кордону з голодуючими південними регіонами та достатньо добре відчувала масштаби голоду в сусідніх регіонах. До того ж, грабіжницька та насильницька політика більшовицького уряду зумовила катастрофічне становище жителів Уманщини також. 
Аналіз досліджень. В радянській Україні з'являлися історичні дослідження, у яких факт голоду 1921-1923 pр. не замовчувався, однак всіляко спотворювався. У 1923 р. в праці М. Гуревича «Голод и сельское хозяйство Украины» подано інформацію про голод на території України (Гуревич, 1923). Після цієї праці тема голоду знайшла відображення в дослідженнях А. Хоменка (Хоменко, 1927), В. Балієва, Г. Діденка (Діденко, 1962), Ю. Полякова (Поляков, 1975) та інших авторів. У період «перебудови» історики, публіцисти, літератори, громадські діячі звертали особливу увагу на дослідження радянських голодоморів, перш за все Голодомору 1932-1933 рр. З'явилися нові публікації про голод 1921-1923 рр. О. Мовчана (Мовчан, 1988), Є. Хенкіна (Хенкін, 1988) та ін., однак у цих працях не проаналізовано діяльність та прорахунки партійних і державних органів щодо недопущення та подолання голоду. 3 відновленням незалежності України історики отримали можливість вільно досліджувати раніше табуйовані теми радянського минулого, розпочалися процеси переходу від марксистсько-ленінських догм на нові методологічні засади. Значну роботу 3 вивчення голоду здійснює С. Кульчицький (Кульчицький, 1993), з-під чийого пера виходили i продовжують виходити цінні наукові дослідження голоду в Україні. У працях О. Мовчан (Мовчан, 2002) висвітлюються питання допомоги голодуючим та різні аспекти голоду.

Тема голоду 1921-1923 pp. розкрита в дисертаційних дослідженнях Б. Драмарецького, В. Силантьєва, В. Кириленка (Кириленко, 2015). Значний внесок у вивчення регіонального виміру голоду зробили історики-краєзнавці, в першу чергу південних регіонів України. Для написання своїх праць вони використовують масив документів 3 місцевих архівів, вивчають допомогу закордонних організацій голодуючим, аналізують регіональну за загальнодержавну пресу. У 1921-1923 рр. голод, щоправда в менших масштабах, був відчутний і у сусідніх з південними регіонами губерніях. Однак регіональний аспект означеного голоду на Уманщині не став предметом окремого дослідження.

Мета статті полягає у дослідженні відображення теми голоду 19211923 рр. на Уманщині у еgо-документах родини Курінних.

Виклад основного матеріалу. Важливим джерелом 3 вивчення історії Уманщини кінця XIX - перших десятиліть XX ст. є щоденник відомого громадського діяча, адвоката Петра Федоровича Курінного (1852 - 1931). На сторінках щоденника П. Ф. Курінний детально фіксував події, що відбувалися у його житті та навколо нього. Часто передав зміст розмов зі своїми знайомими, колегами та друзями, настрої суспільства 3 найактуальніших питань життя міста та країни. Йог осин, відомий український вчений, археолог, фундатор музейної справи Петро Петрович Курінний (1894-1972) до 1924 р. проживав в Умані, займався педагогічною та громадською діяльністю. Окрім цього П. П. Курінний листувався з відомими київськими вченими та музейниками у справі організації та діяльності уманського музею. У науковому архіві Інституту археології НАН України, в особистому архівному Петра Петровича Курінного зберігається значний масив еgо-документів його та його батька. У 
листуванні з рідними, знайомими, колегами відображено основні проблеми та побут мешканців України у 1920-1930-ті рр., зокрема і в голодні 19211923 роки.

У листі до Данила Щербаківського (1877 - 1927) П. П. Курінний, окрім вирішення власних справ інформує вченого про важке становище мешканців Уманщини, які у голодний рік опинилися без допомоги держави та задавлені непомірними податками. У листі від 21 серпня 1921 р. П. Курінний пише: «...живу так, аби дотягти до вечора, та вже часом почуваю на собі передумови недалекої «голодухи». Городи, хліба - вигоріли, а решта йде на голодаючих Сходу. Отже справді виходить мовляв по Свангельському - «самі себе й один одного Христу-Богу віддамо». Уявляю як Ви всі живете! Певне якась містерія шкелетів не більше, але й не менше...» (НА ІА НАНУ, ф. 9, спр. 168/к-468. Арк. 1.).

3 особистих документів, збережених у архіві П. П. Курінного чітко простежується, що голод 1921 р. був зумовлений не лише складними погодними умовами, але й деструктивною політикою радянської влади. Зокрема, чернетка заяви до сільської Продподаткової комісії Івангородського передмістя м. Умань, написана у 1922 р. П. П. Курінним свідчить про непомірні податки, що запроваджувалися новою владою. Згідно 3 цим документом, родина Курінних (складалася 35 сімейств (15 осіб) володіла 6 1/2 десятин польової землі. Попри те, що майже вся площа була засіяна (не вдалося засіяти та обробити $1 / 4$ десятин незручного для оброблення лужка), врожай був настільки малим, що зібраного зерна не вистачало ні для здачі продподатку, ні для забезпечення сім'ї хлібом до нового врожаю, ні для збереження посівного матеріалу для наступної посівної кампанії. Причини поганого врожаю П. П. Курінний виокремлював такі:

1. Відсутність у родини власного інвентаря та насіння, через що частина землі була здана спільнику Івану Тичинському та монахам.

2. 3 великої сім'ї лише 6 осіб могли працювати біля землі (батько П. Ф. Курінний та його дружина були занадто старі для праці, зять був призваний до Червоної Армії, діти (5 осіб) занадто малі для праці, сестра Поліна була на останніх місяцях вагітності. 3 тих 6 осіб, які могли працювати біля землі П. П. Курінний та його брат Дмитро Курінний були державними службовцями (працювали в I трудовій школі та уманській Райфілії відповідно) і більшість часу проводили на службі, тому не могли повноцінно обробляти землю.

П. П. Курінний звертався до сільської влади з проханням звільнити сім'ю від сплати продподатку, однак судячи зі ще однієї заяви від 16 березня 1922 р. стає зрозуміло, що задовольнити прохання сім'ї сільська рада відмовилася.

Окрім непомірних податків додавало селянам клопоту ще й те, що кожного року земельний наділ влада могла перенести на інше місце. 23 травня 1922 р. П. П. Курінний звертався до Повітової земельно-технічної комісії із заявою, в якій повідомляв, що з наявних у власності 6 десятин землі родина змогла знайти лише $13 / 4$ десятини в околицях села Паланки, а інша площа була кудись перенесена владою. Петро Петрович вимагав, аби сільська рада вказала 
де знаходиться інша частина земельного наділу, або ж дозволила обробляти увесь земельний наділ в старих межах (НА IA НАНУ, ф. 10, спр. К-54/11, арк. 7). У ще одній заяві від 1922 р. П. П. Курінний повідомляв сільську комісію Івангородського передмістя м. Умані, що із загальної земельної власності їхнього батька (6 десятин землі), які були розподілені між 4 сім'ями великої родини П. Ф. Курінного, знайдена і своєчасно оброблена лише одна ділянка землі (1 3/4 десятин). Попри розшуки серед сусідів та заяви до сількомісії, решту земельних площ не було наділено та відповідно не було засіяно. У зв'язку з цим родина інформувала сільську владу, що відмовляється на посівну кампанію 1922 року від 4 1⁄4 десятин «незнайденої» землі та просить не враховувати їі для оподаткування (НА ІА НАНУ, ф. 10, спр. К-54/11, арк. 6).

Аналізуючи щоденникові записи П. Ф. Курінного стає очевидним , що передумови початку голоду закладалися більшовицькою владою ще на початку посівної кампанії 1921 р. На початку березня 1921 р. загони червоноармійців в селі Подібна заборонили селянам розпочинати роботу в полі до того часу, допоки не отримають з села 70 возів податку. У відчаї селяни говорили, що більшовики заважають займатися господарством, однак вимагають хліба. «Мы так можем дожить до того, что и сами не будем иметь хлеба, - и они (большевики) будут голодны» - майже пророче говорили селяни на початку 1921 року (Торгало, 2014: 234). Сдине, що не збулося з цих слів - більшовики не залишилися без хліба, тому що вимітали його до останньої зернини 3 селянських засік. 26 березня 1921 р. більшовики скликали селян Подібної на збори та взяли 20 заручників до того часу, допоки селяни не виконають план здачі податків - 150 возів продовольства.

Такі заходи нової влади викликали обурення місцевого населення. Додавала невдоволення і кадрова політика більшовицької влади. Представники радянської влади на місцях (як правило комнезами) брали заручників, збирали податки, придумували абсурдні вказівки. Однак членами Комнезамів були зазвичай неосвічені та неавторитетні мешканці громади. Зокрема, Головою Волосного Комнезаму на Уманщині був Яків Печериця - колишній двірник П. Ф. Курінного. У селі Краснопілка ситуація була не кращою: «заправилами», тими, які старе знищували, а нове встановлювали - теж були не кращі люди сільської громади. Очолював радянську владу на селі чоловік, який був засуджений на два роки покарання волі за крадіжку. «Тепер хозяєва не мають голоса, а тільки якісь острожники!», - бідкалися селяни П. Ф. Курінному (Торгало, 2014:248).

Незважаючи на своє пролетарське та селянське походження, представники нової влади поводилися зверхньо. П. Ф. Курінний кінні екіпажі більшовицької влади порівнював 3 панськими, адже при зустрічі 3 ними пішоходи і перевізники були змушені розходитися по боках дороги для того, щоб більшовики проїхали без перешкод (Торгало, 2014: 235). Навіть під час похоронної процесії, коли жителі Івангородського передмістя супроводжували труну з покійником до монастиря, то зустрічний автомобіль більшовиків розігнав процесію. На початку травня 1921 р. в Умань приїхав член ЦК КП(б)У Володимир Затонський, якого місцеве населення називало «Начальником 
Правобережної України». Уманчан вразила розкішність, яка оточувала нового керівника: «вагон раскошный, убранство царское, чинопочитание, "строгость дисцыплины, возможные только при монархизме''...Словом, видно, что высшему начальству хорошо». Особливо контрастно це виглядало на фоні збіднілого населення (Торгало, 2014: 249).

Ще одна 3 проблем цього часу - постійне зростання цін та шалена інфляція. Якщо до війни П. Ф. Курінний купував бублик за $1 / 2$ копійки, то у 1921 р. його вартість складала 100 рублів. Радянські гроші неохоче приймали купці, а «керенські» були недійсними. Винними в цьому більшість населення вважали євреїв, які в основному займалися торгівлею і «то підвищували, то занижували» курс валюти з метою заробітку. У січні 1922 р. вартість чобіт на базарі коливалася від 200 тисяч до 2-х мільйонів рублів, але можливості їх купити у родини Курінних не було. Коштів не вистачало навіть для придбання на базарі найнеобхідніших продуктів харчування. У квітні 1922 р. на сторінках щоденника знову знаходимо відомості про шалену інфляцію на Уманщині. За тиждень вартість фунту сала зросла 3500000 рублів до 2-х мільйонів рублів. Радянські гроші неохоче приймали на місцевих базарах, більшість людей розраховувалися бартером: речі міняли на продукти чи зерно (Торгало, 2014: 301).

Радянська влада встановлювала великі розміри податків та жорстко контролювала процес вилучення продовольства у населення. У квітні $1921 \mathrm{p}$. біля околиць села Коржова П. Ф. Курінний став свідком того, як понад 100 возів з хлібом і стадо худоби супроводжували червоноармійці як «розверстку» 3 якогось села. Постійні реквізиції продовольства та худоби складали враження «беспощадного грабежа (Торгало, 2014: 239). Через кілька днів автор щоденника став свідком подібної картини, коли більшовики гнали багато худоби реквізованої в селі Колодистому. Окрім цього щоденно більшовики перевозили тони збіжжя, вилученого в селян як продрозверстка (Торгало, 2014: 244). У червні 1921 р. на родину П. Ф. Курінного було покладено зобов'язання здати 6 пудів зерна до сільської ради. На Івангородське передмістя Умані покладалася така розверстка: хліба 2104 пуди, картоплі 2275 пуд., худоба - 19 шт. (148 пуд.), свиней - 16 шт. (56 пуд.), овець - 62 шт., яєць - 32000 шт., масла - 35 ф. і щоденно молоко від корів. (Торгало, 2014: 253). Великі розміри податків призвели до того, що вже 3 липня 1921 р. серед уманчан були поширені розмови про те, що в селах люди залишилися без хліба. 15 серпня 1921 р. Комнезам Івангородського передмістя видав розпорядження про додатковий збір 1 пуду зерна 3 кожної десятини землі для допомоги голодуючим (Торгало, 2014: 259). Якщо в господарстві не було зерна, то 3 господарів вимагали свиту, чоботи чи інші дороговартісні речі. Окрім цього Комнезам проводив облік та фіксував скільки в господарстві фруктових дерев, скільки росте картоплі, капусти та іншої городини. В залежності від кількості посадженого встановлювався розмір натурального податку для кожного господарства. 3 фруктового дерева потрібно було сплатити 3 фунти вишень (в господарстві П. Ф. Курінного більшість фруктів червоноармійці обнесли 3 дерев ще до того, як вони дозріли) (Торгало, 2014: 259). У січні 1922 р. селяни 
Івангородського передмістя переймалися тим, як сплатити продподаток. Багато хто сидів без хліба і не мав чим сплатити податок, були ж і такі, що сплачували податок, однак потім самі залишалися без продовольства (Торгало, 2014: 280).

Окрім цього тягарем на селян падали і різноманітні контрибуції, які час від часу накладалися радянською владою. У квітні 1921 р. на селян с. Кочержинці було накладено контрибуцію 3 мільйони рублів на користь керівника сільської земельної комісії, який постраждав від пожежі (Торгало, 2014: 240). 20 березня 1922 р. у щоденнику зафіксовано, що влада розставила по дорогах і на базарі війська, які забирали з возів усі продукти, а особливо зерно у приїжджих. У травні 1922 р. додатковий податок для підтримки голодуючих було накладено на селян Соколівки.

Боротьбу з голодом, в першу чергу у поволзьких губерніях, радянська влада намагалася використати для антирелігійної боротьби. У травні 1922 р. священник з села Собківки розповідав П. Ф. Курінному, що спеціальна Комісія приїздила до церкви забрати на користь голодуючих церковні цінності, але зійшлися сільські жінки і не дали вилучити церковні речі. Комісія поїхала у сусіднє село Громи, де вилучила в церкві майно. 3 Охматівської церкви для підтримки голодуючих забрали чашу та інші цінності (Торгало, 2014: 315).

Ще одним елементом ленінської голодотворної політики в Україні було насадження в суспільстві атмосфери страху, доносів та репресій. Відповідно до рішення Ради праці і оборони про застосування надзвичайних заходів під час вилучення продподатку до сіл дозволялося вводити військові частини, які мали повноваження «негайно вживати найрішучіші заходи примусового характеру» для вилучення продовольства. На сторінках щоденника неодноразово зафіксовано, що місцеве населення намагалося уникнути зустрічі 3 більшовицькими військами. Люди передавали один одному інформацію про шляхи, якими пересувалися війська, аби оминути зустрічі з ними. «Какое скверное время! Все боятся войска, как дикой орды... Давно ли мы смотрели на солдат как на защитников, а теперь каждый 'товарищ' большевик наводит на каждого гражданина уныние, страх и ненависть»... (Торгало, 2014: 250). Ненависть до більшовицького війська була спричинена і неодноразовими грабунками населення. Для прикладу, 7 червня 1921 р. на село Ладижинку здійснив набіг кавалерійський загін більшовиків, які пограбували всіх на базарі, а потім базар розігнали (Торгало, 2014: 251). Через кілька днів подібні звістки лунали $з$ села Псярівка, 3 містечка Дубова та 3 інших населених пунктів Уманщини. У липні 1921 р. на с. Подібна напали кавалеристи 45 дивізії які окрім того, що здійснювали обшуки в населення та вилучали продовольство, кіньми їздили по людських городах то витолочували посаджену городину. Подібна атмосфера панувала всюди. Автор зазначав: «куда не посмотрю всюду большевики и шпионы, даже в поле...А в городе судят три «чрезвычайки» (Торгало, 2014: 240).

У жовтні 1921 р. на сторінках щоденника зафіксовано, що голод відчула родина Петра Федоровича Курінного. У цей час у них не було хліба, борошна, цукру. Замість чаю родина пила теплу воду. Щоб виправити ситуацію та заробити продукти для харчування Петро Федорович влаштувався працювати 
на млині в селі Соколівка, його син П. П. Курінний працював на кількох роботах в Умані (державних і ще додатково розвантажував вагони на вокзалі), то на Великодній стіл у 1922 р. родина зуміла дістати калач, шинку, яйця, сир і ковбасу. Хоча автор зазначив, що багато сімей не змогли накрити такого столу. Під час освячення продуктів біля церкви було багато голодуючих, які просили милостиню (Торгало, 2014: 294). У червні 1922 р. фіксував: «ничего у меня дома: ни завтракать, ни обедать... Кусочек хлеба и одна маленькая редиска». Такою ж ситуація була і в липні: «у нас теперь нет ни молока, ни хлеба, ни сала, ни муки» (Торгало, 2014: 321). Попри нестачу продуктів у населення найбільша ïх концентрація була на залізничному вокзалі. Навесні 1921 р. П. Ф. Курінний зафіксував у щоденнику, що червоноармійці пересилають масу вилученого продовольства у селах Уманщини потягом своїм рідним (Торгало, 2014: 239).

Спілкуючись 3 селянами П. Ф. Курінний фіксував їхні думки на сторінках щоденника. 72-річний житель с. Подібна розповідав Курінному: «розказували батьки, що за поміщика теж робили на панів і пряли мітки, але ж тоді хліба не збирали із селян i не знущались так, як тепер знущаються i ограбляють народ... .і казна требувала роботи (на 3 дні), але ж вона і помагала людям. То називалось '”панщина', а тепер воля» (Торгало, 2014: 266).

Напевно найсильніше голод родина Курінних відчувала взимку 1922 року. Саме в цей час П. Ф. Курінний часто записував на сторінках щоденника подібні думки: «Я вижу, что у меня дома настоящий голод... Вола сьел бы такой аппетит, есть хочется, а нечего... Безнадежность положения заставляет думать, что так жить трудно и невыносимо... Лучше умереть, но где же и как умирать, когда нет смерти? Страдать надо и жить надо, и тут старость ни при чем» (Торгало, 2014: 277).

На сторінках щоденника П. Ф. Курінний розмірковував про економічну політику більшовицької влади, яка спричинила важке становище населення Уманщини. Декларовані гасла зрівняння всіх у правах на практиці зводилися до того, що робітники, залишилися роботи і чекали подання, а інтелігенція, заради порятунки від голоду була змушена працювати на чорнових роботах. 3 колишніх працівників сформувався клас грабіжників, а 3 інтелігенції недосвідчені працівники фізичної праці. В результаті всі були відірвані від своєї звичної праці (Торгало, 2014: 277). В суспільстві панувала атмосфера недовіри до радянських газет і радянського уряду. Причиною цієї недовіри автор щоденника вважав те, що радянська влада не виконала жодної своєї обіцянки. Зокрема у народу все забрали, а натомість нічого йому не давали; в країні була цілковита розруха і не було надії на покращення життя; від голоду, хвороб і несправедливості постійно вмирали люди; безвинно і несправедливо було розстріляно «неисчислимое множество» громадян, багатьох утримували в тюрмах і підземеллях; влада брала хабарі і нечесно вела громадські та державні справи; був відсутній правовий суд. В податках і повинностях проявлялися свавілля, грабунки та знущання на людьми. Просвіта народу зупинена, школи закривалися, православна церква переслідувалася, робота підприємств не відновлена. Бентежило П. Курінного і те, що не було виборності влади, а нав'язані народу кандидати утримували владу через різноманітні репресивні 
заходи та фальсифікації під час виборів (Торгало, 2014: 301). Висловлені думки Петра Курінного свідчать про глибоке розуміння ним соціально-економічної та політичної ситуації в країні, причин голоду та змісту антинародної політики ленінської влади.

В місті відбувався збір допомоги для голодуючих. У січні 1922 р. на залізничній станції «Умань» повісився комуніст, який був відповідальний за збір коштів для підтримки голодуючих. Причиною самогубства було те, що він розтратив і крав гроші, а коли нестачі не вдалося замовчати - повісився. (Торгало, 2014: 278). 3 лютого 2022 р. на сторінках щоденника зафіксовано інформацію про голодуючих, які прибували до Уманщини 3 Поволжя, Катеринославської та інших голодуючих губерній. В деяких селах Уманщини вони грабували і вбивали людей. Багато випадків голодних смертей було зафіксовано на залізничній станції та у вагонах потягів. Там замерзали i вмирали обезсилені люди, які прибували до Умані з надією врятуватися від голодної смерті (Торгало, 2014: 285). У квітні 1922 р. П. Ф. Курінний був свідком того, як на місцевому кладовищі в одну могилу ховали десять дітей 3 дитячого будинку, які вмерли від голоду.

В голодні роки припинили свою роботу багато шкіл у селах Уманщини. Причиною цього було те, що селяни не мали можливості утримувати школу. «Нас ограбили, хліб забрали непомірними, страшними продналогами. У нас немає чого їсти, одягтись нема в що, де ж нам і звідки ми будемо держати школу? Нехай діти сидять дома, менше буде комуністів», - говорили П. Ф. Курінному жителі Соколівки (Торгало, 2014: 288).

Таким чином, проаналізувавши родинний архів Курінних можемо дійти висновку, що у еgо-документах Курінних зафіксовано відомості про перебіг голоду 1921-1923 рр. в Україні, зокрема на території Уманщини. 3 мемуарів та листів Курінних увиразнюється картина, що першопричиною голоду 19211923 pp. була посуха, ускладнена господарською розрухою села. Ця першопричина ускладнювалася політикою більшовицької влади, яка встановлювала надмірні розміри податків, накладала контрибуції та здійснювала відвертий грабіж селянства. Уманщина відчула голод 19211923 рр. не так катастрофічно, як південні губернії України, однак була задавлена великими податками. Досить часто селяни не мали чим сплатити податки, або ж після їх сплати залишалися без запасів продовольства.

\section{СПИСОК ВИКОРИСТАНИХ ДЖЕРЕЛ І ЛІТЕРАТУРИ}

Гуревич, 1923 - Гуревич М. Б. Голод и Сельское Хозяйство Украины. Очерк / Матвей Борисович Гуревич. Харьков: Первая Государственная Типография им. тов. Петровского Г.И., 1923. 47 с.

Диденко, 1962 - Диденко Г. Д. Рабочий класс Украины в годы восстановления народного хозяйства (19211925) / Григорий Демьянович Диденко. К.: Изд-во АН УССР, 1962. 375 с.

Кириленко, 2015 - Кириленко В. П. Голод 1921-1923 років у Південній Україні. Дис. ... канд. іст. наук. Міністерство освіти і науки України; Миколаївський національний університет ім. В. О. Сухомлинського. Миколаїв, 2015. 230 с.

Кульчицький, 1993 - Кульчицький С. В. Невідомі сторінки голоду 1921-1923 рр. в Україні / С. В. Кульчицький, О. М. Мовчан. К.: Ін-т історії України, 1993. 70 с.

Мовчан, 2002 - Мовчан О. М. Терор голодом в Україні в 1921-1923 роках / О. М. Мовчан // Проблеми історії України: факти, судження, пошуки. Київ: Інститут історії України НАН України, 2002. №7. С. 66-78. 
Мовчан, 1988 - Мовчан О. Н. Трудящиеся УССР в борьбе с продовольственным кризисом при переходе к нэпу / Ольга Николаевна Мовчан. К.: Наукова думка, 1988. 124 с.

НА ІА НАНУ - Науковий архів Інституту археології НАН України

Поляков, 1975 - Поляков Ю. А. 1921-й: победа над голодом / Юрий Александрович Поляков. М.: Политиздат, 1975. $112 \mathrm{c}$.

Торгало, 2014 - Умань і уманчани очима П. Ф. Курінного / Уклад. Ю. В. Торгало / Умань: Видавець «Сочінський», 2014. 428 с.

Хенкин, 1988 - Хенкин Е. М. Очерки истории борьбы Советского государства с голодом (1921-1922)/ Евель Моисеевич Хенкин. Красноярск: Изд-во Красноярского ун-та, 1988. 171 с.

Хоменко, 1927 - Хоменко А. П. Населення України (1897-1927 рр.) / Арсеній Петрович Хоменко. Харків: Державне видавництво України, 1927. 79 с.

\section{REFERENCES}

Gurevich, 1923 - Gurevich M. B. Golod i Selskoe Khoziaistvo Ukrainy. Ocherk [Famine and agriculture of Ukraine. Essay] / Matvei Borisovich Gurevich. Kharkov: Pervaia Gosudarstvennaia Tipografiia im. tov. Petrovskogo G. I., 1923. 47 s. [in Russian]

Didenko, 1962 - Didenko G. D. Rabochii klass Ukrainy v gody vosstanovleniia narodnogo khoziaistva (1921-1925) [Working class of Ukraine in the years of restoration of the national economy (1921-1925)] / Grigorii Demianovich Didenko. K.: Izd-vo AN USSR, 1962. 375 s. [in Russian]

Kyrylenko, 2015 - Kyrylenko V. P. Holod 1921-1923 rokiv u Pivdennii Ukraini [The famine of 1921-1923 in Southern Ukraine]. Dys. ... kand. ist. nauk. Ministerstvo osvity i nauky Ukrainy; Mykolaivskyi natsionalnyi universytet im. V. O. Sukhomlynskoho. Mykolaiv, 2015. 230 s. [in Ukrainian].

Kulchytskyi, 1993 - Kulchytskyi S. V. Nevidomi storinky holodu 1921-1923 rr. v Ukraini [Unknown pages of the famine of 1921-1923 in Ukraine] / S. V. Kulchytskyi, O. M. Movchan. K.: In-t istorii Ukrainy, 1993. 70 s. [in Ukrainian].

Movchan, 2002 - Movchan O. M. Teror holodom v Ukraini v 1921-1923 rokakh [The famine terror in Ukraine in 1921-1923] / O. M. Movchan // Problemy istorii Ukrainy: fakty, sudzhennia, poshuky. Kyiv: Instytut istorii Ukrainy NAN Ukrainy, 2002. №7. C. 66-78. [in Ukrainian].

Movchan, 1988 - Movchan O. N. Trudiashchiesia USSR v borbe s prodovolstvennym krizisom pri perekhode $\mathrm{k}$ nepu [Workers of the USSR in the fight against the food crisis in the transition to the nep] / Olga Nikolaevna Movchan. K.: Naukova dumka, 1988. 124 s. [in Russian]

NA IA NANU - Naukovyi arkhiv Instytutu arkheolohii NAN Ukrainy [Scientific archive of the Institute of Archeology of the National Academy of Sciences of Ukraine] [in Ukrainian].

Poliakov, 1975 - Poliakov Iu. A. 1921-i: pobeda nad golodom [1921: victory over hunger] / Iurii Aleksandrovich Poliakov. M.: Politizdat, 1975. 112 s. [in Russian]

Torhalo, 2014 - Uman i umanchany ochyma P. F. Kurinnoho [Uman and Uman residents through the eyes of P. F. Kurinnyi] / Uklad. Yu. V. Torhalo / Uman: Vydavets «Sochinskyi», 2014. 428 s. [in Ukrainian].

Khenkin, 1988 - Khenkin E. M. Ocherki istorii borby Sovetskogo gosudarstva s golodom (1921-1922) [Essays on the history of the struggle of the Soviet state against hunger (1921-1922)] / Evel Moiseevich Khenkin. Krasnoiarsk: Izd-vo Krasnoiarskogo un-ta, 1988. 171 s. [in Russian]

Khomenko, 1927 - Khomenko A. P. Naselennia Ukrainy (1897-1927 rr.) [Population of Ukraine 1897-1927] / Arsenii Petrovych Khomenko. Kharkiv: Derzhavne vydavnytstvo Ukrainy, 1927. 79 s. [in Ukrainian] 